from enabling parents to obtain the size of families that they would wish.

Throughout the book Simon's own position, as summarized just above, is contrasted with the latter-day Malthusians whom he wishes to discredit. There are numerous quotations, some from learned articles and monographs, but most from popular books, newspaper articles and advertisements, designed to illustrate the whole range of contemporary pessimism. The style is kept deliberately informal and colloquial, while the author's convictions are often set out in a highly personal way. Now and then this mode of presentation becomes a little trying, but in general the argument is clearly and effectively conveyed, without either condescension or oversimplification. In view of the range and complexity of the topics that are covered, this is a considerable feat.

In judging the merits of Simon's argument, two distinct tests are relevant, corresponding to the two aims which the book tries simultaneously to achieve. The first aim is destructive: to undermine and cast doubt on current neo-Malthusian pessimism. The second is to offer an alternative view of the world, an acceptable analysis of events, relationships and trends. Not surprisingly perhaps, the author succeeds more completely with the former task than with the latter.

The process of demolition is carried out with skill and resource. In part, the prophets of doom are discredited by the various excerpts from their own works, many of which make sorry reading. But the main weight of the argument rests on the evidence of the past and on general economic reasoning, both of which are often neglected or undervalued by the pessimists, and which the author presents extremely well. Unfortunately, the views that he attacks are widely held and influential. By challenging them so effectively Simon has performed a real service.

When it comes to his alternative view of the world, there is more room for doubt. At a number of points the argument seems to me to be too unqualified or incautious, while in some respects it is less complete than it should be. For example, his generally admirable discussion of natural resources is marred by a failure to consider the possibility that oil is a special case. Because of what are often presented as facts of geology, it may be that the period of cheap oil was a historical accident, a bonanza which cannot be repeated. If this is so, and given the unique convenience and properties of petroleum as a fuel, a secular rise in the real price of oil is not at all to be ruled out; and it is insufficient to dismiss the increases of the 1970s, as Simon does, as being due simply to the machinations of OPEC. Moreover, because of its role in the world economy, and the uneven distribution of productive capacity and reserves, the effects of oil price increases are potentially much more damaging than in the case of other raw materials. Simon does not go into this, and his two chapters on energy are superficial.

As to population, a clearer distinction could have been made between two aspects of the question: the absolute size of a population, and its rate of growth. More space should also have been given to two arguments against rapid population growth: one is the possible congestion arising from higher densities, while the other is that a rapidly growing labour force may lead to a more unequal distribution of income. Again, Simon states correctly that a judgement on the net advantages of population growth may depend on how one weighs more distant costs and benefits in relation to those which are nearer in time. But he says nothing about how this valuation of time should be made, nor about the suitability of using for this purpose the actual rates of interest that are established in financial markets.

More worrying is an occasional tendency to rather serious overstatement. Thus in the concluding chapter, we are told that "The standard of living has risen along with the size of the world's population since the beginning of recorded time" (p.345). This is false. One can find phases of history - as for example in England from the mid-thirteenth century till around the end of the seventeenth - when a rise in population is thought to have led directly to a fall in real wages, and vice versa: the simple Malthusian model seems to fit the facts. It is probably only in the modern era that this inverse connection has been broken, first in the industrial countries and more recently in other parts of the world: possibly it holds good even now in some of the poorest and least developed countries. Here and at some other points of the argument, Simon has yielded to temptation: he makes overconfident generalizations about relationships that are subject to considerable variety and change.

Despite these reservations, the book is much to be recommended. It is possibly the best available modern treatment of the issues that Malthus raised.

P. D. Henderson is a Professor in the Department of Political Economy at University College London.

\title{
The hunting of the rorqual
}

\section{Arthur Bourne}

The History of Modern Whaling. By J.N. Tønnessen and A.O. Johnsen. Pp.798. UK ISBN 0-905838-23-8; US ISBN 0-52003973-4. (C. Hurst, London/University of California Press: 1982.) $£ 22.50, \$ 45$.

THE POPULAR image of whaling as the harpooneer, lance in hand, standing bravely on the prow of a row-boat ready to do battle with Leviathan, is enshrined in the writings of authors like Melville and Bullen. The picture is a romantic one but, as both those writers knew, whaling was far from romantic. It was - and its rump is a tough business, firmly based on hard commercial interests. If there is little romance in whaling, as compensation there is a world of fascination and of no period is this more true than when the new whaling industry was emerging from the old.

The modern epoch really began in Fobruary 1864 when a small steampowered vessel, the Spes et Fides, sailed out of Tønsberg in south-eastern Norway for the whaling grounds off Finnmark. It is the story of the unfolding of that modern history which is the subject of Den Moderne Hvalfangsts Historie, of which the volume under review is a muchcondensed English translation. In it the authors have cleverly drawn together the strands of the technical, sociological and financial developments of that period.

The birth of the modern whaling industry will always be associated with one man, the owner and skipper of the Spes et
Fides, Svend Foyn. Why he was to be the leading force and why Norway should have been the birthplace are interesting questions. As the authors show, the Americans dominated the old whaling scene and were experimenting with new methods at the same time as Foyn. Even his idea of combining an explosive harpoon fired from a cannon mounted on a steampowered boat was not original, and he was not the first man to realize that the future of whaling lay in the chasing, catching and processing of the great rorquals. The real answers to those questions lie not only in the technical inventiveness of the various contenders - of which there were many but also in the social and economic changes that were occurring at the time.

In the middle of the nineteenth century the Americans were looking increasingly inwards. The opening of the West with its vast prairies and potentially enormous mineral wealth seduced capital and labour away from the coast and the sea. In Norway the situation was very different. With little hinterland and an increasing population which the nation's industry and agriculture could not sustain, thousands of Norwegians, in common with many other Europeans, sought their futures in North America. By one of those quirks of fate, America's retreat from the sea opened up an opportunity for the Norwegians left at home. They were quick to fill the gap, and, combined with the expansion of sea-tradc generally, this provided the stimulus for the 
growth in Norway's maritime industry.

At the same time the economics of whaling were propelling technical developments along parallel lines in several countries. The stocks of right whales "right" because they were slow swimmers and floated when killed - had been so decimated by the middle of the century that they were unable to support a viable industry. The interest of the whalers turned to the rorquals which "teemed in the seas", but which were too swift for the row-boats and, moreover, sank when killed. One of the first to experiment with explosive harpoons was the American T.W. Roys, who invented a harpoon-throwing gun and set out to see "if a cargo of oil could be obtained from whales previously unavailable to mankind"'. There were other innovators and other developments, one of which was, the authors believe, of decisive importance to Foyn's own ideas. This was the grenade harpoon invented by George Welch in 1867, three years before Foyn's final patent was granted. In many countries similar inventiveness was displayed, but Foyn was the most persistent. He believed in the potential of the rorqual fishery even during his experiments with the Spes et Fides when failures lost him money, he kept going. He was in the end the right man at the right time.

The first of the rorqual stocks to follow the right whales to extinction was, not surprisingly, the Finnmark stock. From then on it was for the whaling companies a matter of geographical expansion and greater sophistication in techniques and ship design. The whalers extended their activities to wherever rorquals could be found and eventually to the waters surrounding the Antarctic continent. It was there that the greatest harvests were to be culled, and where the technical ingenuity of the whalers was again stretched.

The problems were to stay at sea long enough to justify the cost of fitting out a fleet, and to build more powerful and faster catchers. The floating whalefactory, heralding the pelagic whaling industry, extended the range of the catchers, and the introduction of offloading the oil into tankers enabled the fleets to remain at sea for months. From 1937 and the launching of the Japanesebuilt Seki Maru, the catchers became progressively more powerful. However, no matter how long the whalers were on the oceans, nor how sophisticated their equipment, if the whales were not there they could not be caught. Inevitably the Finnmark story was to be repeated again and again, and nation after nation, including Norway, had to abandon pelagic whaling - political ingenuity in conserving whale stocks fell far short of the technical expertise in destroying them.

The whaling industry is neglected by the student of the development of the industrial nations and yet it reflects the social and economic conditions of the times most vividly. It also provides clear insight into the way those conditions forced men to seek means of utilizing resources that had hitherto been out of reach. The story of the whaling industry shows too how difficult it is to maintain an industry based on natural resources, even renewable resources, if immediate commercial considerations over-ride the long-term benefits of rational exploitation and investment.

The authors of this book have achieved a remarkable piece of condensation and R.I.
Christophersen must be congratulated on a fine translation. The only sad thing about this volume is that it is unlikely that we shall ever see an English-language version of the original four-volume work - and that it is equally unlikely that mankind will learn from the mistakes it so amply documents.

Arthur Bourne was an observer at the International Whaling Commission from 1964 to 1968. His great-grandfather was a contemporary and competitor of Svend Foyn.

\section{Cartography: from astrolabe to orbiter}

\section{Helen Wallis}

The Mapmakers. By John Noble Wilford. Pp.414. UK ISBN 0-86245-041-1; US ISBN 0-394-46194-0. (Junction Books/Knopf: 1982.) $£ 9.95, \$ 20$.

A NOTABLE theme in the history of human endeavour is the record of man's survey and mapping of the Earth, the Moon and (by spacecraft) of the nearer planets. Even the earliest surviving records show a surprising degree of sophistication in the cartographic arts. Thus an example of early cadastral mapping has been identified in the depiction of a village found in rock carvings of the Valcamonica in northern ltaly and dating from the second and first millennia BC. The Babylonian world map of about $500 \mathrm{BC}$ is one of the earliest depictions of the cosmos. And two silk maps recently recovered from the Ming tombs show the advanced level reached by the Chinese in the second century BC.

With the development of the geographical sciences in classical Greece, the coordinate system for the mapping of the world was established which is still the accepted method today. Even in the socalled "dark ages" of Europe, a continuing tradition can be traced from the surveys of the late Roman empire through mediaeval times.

The European Renaissance brought about a revolution in mapmaking. The newly invented techniques of engraving made possible the "exactly repeatable picture", and in the late fifteenth century led to the establishment of the mapmaker's craft and the map publishing industry. At the same time European ventures of exploration set in motion the mapping and surveying of the world. A comparable revolution has taken place in the past 50 years with the development of aerial surveys, automated cartography, and mapping from and in space.

The history of the complicated processes involved in these developments can be told in various ways. The role of the mapmakers themselves is often subordinated to the record of the artefacts, the atlases, maps and globes. John Noble Wilford in his new history of cartography sets out to correct this bias. In The Mapmakers he tells the story of "the multitude of diverse characters", ranging from scholars and scientists to clockmakers, schoolteachers and spies, aviators and technicians, who stand out in the history of cartography. Although he has not spent a lifetime working with maps as such, his professional post as science correspondent for The New York Times makes him well qualified to identify the pioneers and innovators in the history and explains his concern to bring out the drama of personal triumph. As professional mapmakers normally write their reports in "the bloodless language of the specialized

Surveyors at work in the eighteenth century - detail from a map of Warwickshire by Henry Beighton, 1728. 